\title{
PREPARATION OF MANUSCRIPTS
}

ABSTRACT - An abstract of 250 or fewer words is required for articles; abstracts do not accompany notes or other comments.

GENERAL

Important references for format preparation are: 1) The Journal of Paleontology "Instructions for Authors" (Volume 69, pages 182-186); 2) Suggestions to Authors of the Reports of the United States Geological Survey (seventh edition) 1991; and 3) The Chicago Manual of Style (fourteenth edition) 1993. Where there is conflict, current Journal style prevails; any recent issue provides a useful guide, but note changes with the 69:182186 "Instructions for Authors."

All copy must be submitted on either $21.5 \times 28.0 \mathrm{~cm}\left(8 \frac{1}{2} \times 11 \mathrm{in}\right.$.) or A4 standard-weight paper. Submit three copies. Manuscripts must be laser printed or letter-quality typed; dot-matrix printing is not acceptable. Double-space throughout, including references and table and figure descriptions; provide ample margins. Submitted copies need not include original illustrations, but they should be of very high quality; originals may be requested if submitted figures are not of adequate quality. Use metric measurements. A 7.5-10.0 $\mathrm{cm}$ heading is left on the first page above the title. First-page format should follow published examples.

TEXT

Headings. - The style of headings is illustrated by the format of this guide. Two grades of headings are almost always sufficient. Primary headings are centered and typed in all captial letters. Secondary headings are indented, underlined, and followed by a period and two hyphens. The heading for the abstract is not indented, it is capitalized throughout, and it is followed by two hyphens but no period. The first two words of the introduction are capitalized and abut the left margin. Do not end manuscript lines with hyphens.

Systematics. - Format for arrangement of systematic paleontology can be learned from current issues of the Journal. All descriptions of new taxa must be accompanied by a diagnosis, an indication of type specimens and repository, stratigraphic and geographic data, and specific reference to illustrations of the taxon. Particularly note the format, punctuation, and capitalization conventions used in the synonymy.

\section{REFERENCES}

Particular care should be given to reference format. The "Instructions for Authors" provides many examples: note that certain minor stylistic changes were initiated with the $69(1)$ issue.

\section{ILLUSTRATIONS}

Figures. - All illustrations, including maps, geologic sections, and halftone illustrations, must be numbered in the sequence of their first appearance in the text. "Figure" is used rather than "Plate," and therefore line drawing and photographic figures are numbered in sequence. All illustrations, including review copies, must be submitted at publication size. These sizes are: full page, $18.3 \times 23.3 \mathrm{~cm}$; double-column, $18.3 \mathrm{~cm}$; single column, $9.0 \mathrm{~cm}$. Halftone illustrations must be original photographs mounted on black or white cardboard, $21.5 \times 28.0 \mathrm{~cm}$. Photographic subjects must be illuminated from the upper left side, or evenly illuminated. A photograph of a montage is not acceptable. Each illustration must be identified by a numeral but typewritten lettering is not acceptable. Press-on lettering is acceptable but it readily breaks from the original and therefore much care must be used. Line drawings may be either an original or a glossy print mounted on white cardboard. Allow $1.5 \mathrm{~cm}$ at top for printer's label. 


\section{PALEONTOLOGICAL SOCIETY SPECIAL PUBLICATIONS}

The Paleontological Society publishes two series of topical publications. Short Course Notes are published each year in association with the Society's annual short course, held with the Annual Meeting of the Geological Society of America. The Special Publications series includes the proceedings of symposia and other events sponsored by the Society.

\section{Short Courses Notes:}

Echinoderms-edited by T.W. Broadhead and J.A. Waters (1980), 235 p., $\$ 12$.

Lophophorates-organized by J.T. Dutro, Jr., and R.S. Boardman (1981), 253 p., \$12.

Foraminifera-organized by M.A. Buzas and B.K. Sen Gupta (1982), 219 p., $\$ 12$.

Sponges and Spongiomorphs-organized by J.K. Rigby and C.W. Stearn (1983), 220 p., $\$ 12$.

Mammals-organized by P.D. Gingerich and C.E. Badgley (1984), 234 p., \$12.

Mollusks-organized by D.J. Bottjer, C.S. Hickman, and P.D. Ward (1985), 308 p., \$12.

Land Plants-organized by R.A. Gastaldo (1986), 226 p., $\$ 12$.

Fossil Prokaryotes and Protists-organized by J.H. Lipps (1987), 303 p., \$12.

Molecular Evolution and the Fossil Record-organized by Bruce Runnegar and J.W. Schopf (1988), 167 p., $\$ 12$.

The Age of Dinosaurs-organized by Kevin Padian and Daniel J. Chure (1989), 210 p., $\$ 15$.

Arthropod Paleobiology-organized by D.L. Mikulic (1990), 312 p., $\$ 15$.

Analytical Paleobiology-organized and edited by N.L. Gilinsky and P.W. Signor (1991), 216 p., \$15.

Trace Fossils-organized and edited by C. G. Maples and R. R. West (1992), 236 p., $\$ 15$.

Taphonomic Approaches to Time Resolution in Fossil Assemblages-organized and edited by S.M. Kidwell and A.K. Behrensmeyer (1993), 302 p., \$15.

Major Features of Vertebrate Evolution-organized and edited by D. R. Prothero and R. M. Schoch (1994), 270 p., $\$ 15$.

\section{Special Publications:}

Volume 1: The Evolution-Creation Controversy: Perspectives on Religion, Science, and EducationA Handbook. Organized by R.A. Gastaldo and W.F. Tanner (1984), 154 p., $\$ 6.50$.

Volume 2: Paleoecology and Taphonomy of Pleistocene to Recent Intertidal Deposits, Gulf of California. K.W. Flessa (ed.) (1987), 240 p., \$12.50.

Volume 3: Methods and Applications of Plant Paleoecology. W.A. DiMichele and S.L. Wing (eds.) (1988), 171 p., $\$ 12.50$.

Volume 4: Paleotechniques. R.M. Feldmann, R.E. Chapman, and J.T. Hannibal (eds.) (1989), 358 p., $\$ 20.00$.

Volume 5: Paleocommunity Temporal Dynamics: The Long-term Development of Multispecies Assemblies. W. Miller, III (ed.) (1990), 421 p., \$20.00.

Volume 6: Fifth North American Paleontological Convention-Abstracts and Program. S. Lidgard and P.R. Crane (eds.) (1992), 329 p., $\$ 20.00$.

Volume 7: Dino Fest. G. D. Rosenberg and D. L. Wolberg (eds.) (1994), 503 p., \$30.00.

All publications are available by mail order from:

The Paleontological Society

$\%$ Department of Geological Sciences

University of Tennessee

Knoxville, Tennessee 37996-1410

U.S.A.

A check or institutional purchase order must accompany the order. Payment is to be made in \$US to The Paleontological Society. Orders will be shipped 4th class mail; overseas orders should add $\$ 1.50$ US for surface mail.

(NOTE: Communications about the Journal should be addressed to: Journal of Paleontology Subscriptions Office, P.O. Box 1897, 810 East 10th St., Lawrence, KS 660448897.) 